
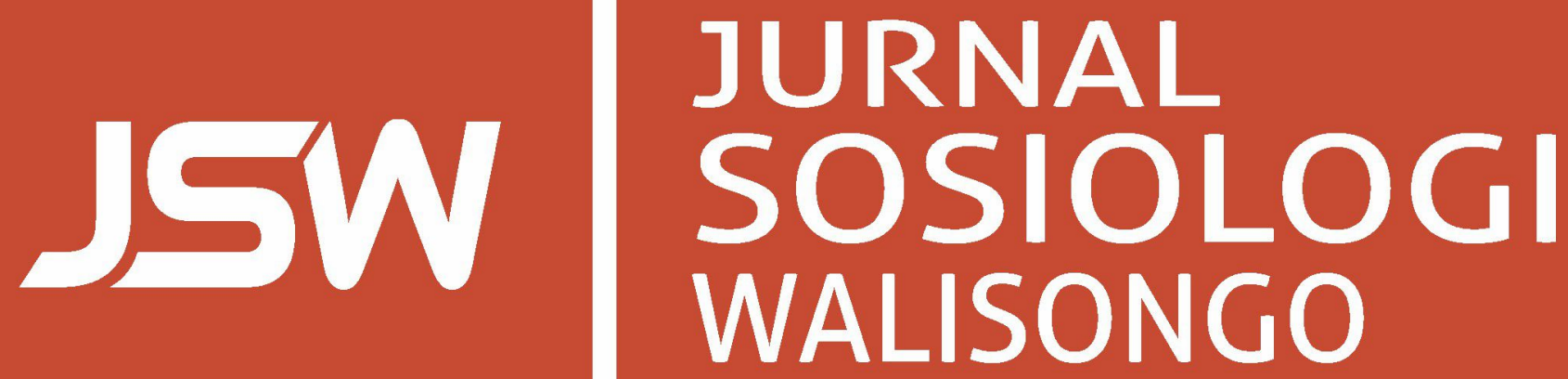

Studi Etnoekologi tentang Nelayan dan Jaring Cantrang

di Kabupaten Rembang

Hesti Rofika Sari, Nugroho Trisnu Brata

Perlawanan Visual Perempuan dalam Poster

Misbah Zulfa Elizabeth

Kearifan Budaya Lokal sebagai Benteng Munculnya Konflik Agama Muhammad Alfan Sidik

Ulama Pasca Sunan Gunung Jati: Jaringan Intelektual Islam Cirebon Abad ke-16 sampai dengan Abad ke-18

Didin Nurul Rosidin

Membangun Harmoni Sosial: Kajian Sosiologi Agama tentang Kearifan Lokal sebagai Modal Dasar Harmoni Sosial David Samiyono

Analisis Komparatif atas Hasil Tracer Study Program Studi Hubungan Internasional dan Administrasi Negara Muhyar Fanani, Akhriyadi Sofian, Kaisar Atmaja, Endang Supriadi

Melihat Indonesia dari Jendela Papua: Kebinekaan dalam Rajutan Budaya Melanesia Akhmad Kadir 

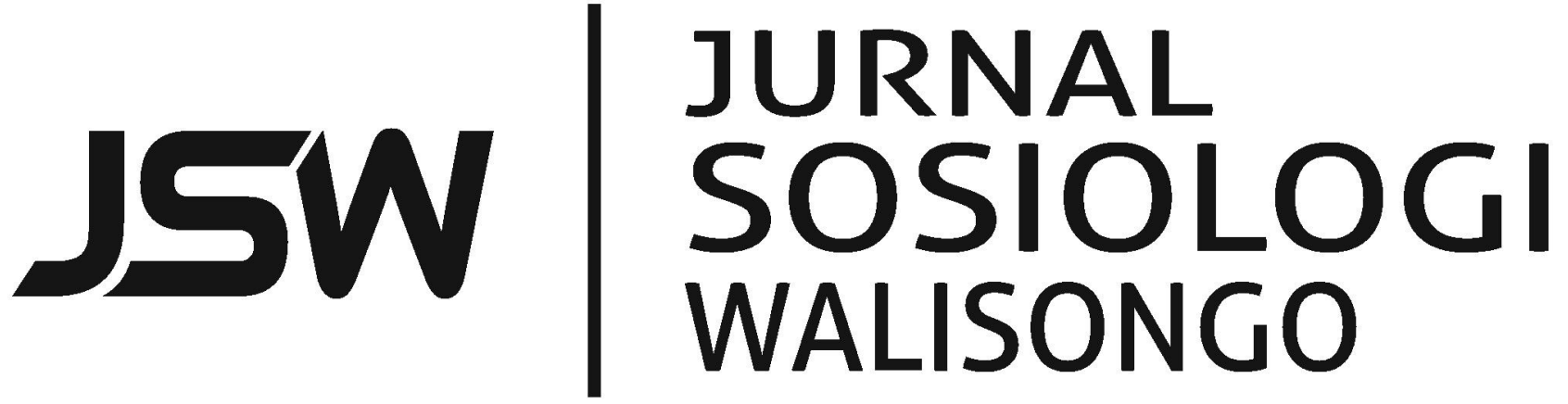

JSW: Jurnal Sosiologi Walisongo - ISSN 2503-3166 (print) ISSN 2503-3182 (online) is a critical, reflective, and transformative academic media that is published by Laboratorium Sosiologi, Fakultas IImu Sosial dan IImu Politik, Universitas Islam Negeri Walisongo Semarang, in the effort for developing the discipline of Sociology having the perspective of unity of sciences. Article is based on research in all division of sociology like sociology of religion, sociology of politic, sociology of law, sociology of development, urban/rural sociology, democracy, social ethic, anthropology, community development, social philosophy, gender, and social welfare.

\section{Editor in Chief}

Misbah Zulfa Elizabeth, Universitas Islam Negeri Walisongo, Semarang

\section{Expert Editor}

Abu Rokhmad, Universitas Islam Negeri Walisongo, Semarang

Muhyar Fanani, Universitas Islam Negeri Walisongo, Semarang

Thohir Yuli Kusmanto, Universitas Islam Negeri Walisongo, Semarang

\section{Editor}

Kaisar Atmaja, Universitas Islam Negeri Walisongo, Semarang

Akhriyadi Sofian, Universitas Islam Negeri Walisongo, Semarang

Nur Hasyim, Universitas Islam Negeri Walisongo, Semarang

\section{Layout Editor}

Helmi Suyanto, Universitas Islam Negeri Walisongo, Semarang

Ulul Azmi, Universitas Islam Negeri Walisongo, Semarang

\section{Publisher}

LABORATORIUM SOSIOLOGI

Fakultas IImu Sosial dan IImu Politik

Universitas Islam Negeri Walisongo

Semarang - Indonesia

\section{Address}

Gedung A - Fakultas IImu Sosial dan IImu Politik (FISIP)

Universitas Islam Negeri Walisongo, Semarang - Indonesia

Jl. Prof. Dr. HAMKA, Km. 2 Tambakaji Ngaliyan Semarang 50185

Phone +62.24 - 76435986

e-mail:jurnal.sosiologi@walisongo.ac.id 


\section{Table of Contents}

Studi Etnoekologi tentang Nelayan dan Jaring Cantrang di Kabupaten Rembang

Hesti Rofika Sari, Nugroho Trisnu Brata (Universitas Negeri

Semarang)

$135-146$

Perlawanan Visual Perempuan dalam Poster

Misbah Zulfa Elizabeth (Universitas Islam Negeri Walisongo,

Semarang)

$147-160$

Kearifan Budaya Lokal sebagai Benteng Munculnya

Konflik Agama

Muhammad Alfan Sidik (STAI Natuna)

$161-176$

Ulama Pasca Sunan Gunung Jati: Jaringan Intelektual Islam

Cirebon Abad ke-16 sampai dengan Abad ke-18

Didin Nurul Rosidin (Institut Agama Islam Negeri Syekh Nurjati,

Cirebon)

$177-194$

Membangun Harmoni Sosial: Kajian Sosiologi Agama tentang

Kearifan Lokal sebagai Modal Dasar Harmoni Sosial

David Samiyono (UKSW, Salatiga)

$195-206$

Analisis Komparatif atas Hasil Tracer Study Program Studi

Hubungan Internasional dan Administrasi Negara

Muhyar Fanani, Akhriyadi Sofian, Kaisar Atmaja, Endang Supriadi

(Universitas Islam Negeri Walisongo, Semarang)

$207-224$

Melihat Indonesia dari Jendela Papua: Kebinekaan dalam

Rajutan Budaya Melanesia

Akhmad Kadir (Universitas Cendrawasih, Jayapura)

$225-246$

Author Guidelines

JSW: Jurnal Sosiologi Walisongo - Vol 1, No 2 (2017) 



\title{
Melihat Indonesia dari Jendela Papua: Kebinekaan dalam Rajutan Budaya Melanesia
}

\author{
Akhmad Kadir \\ Universitas Cendrawasih, Jayapura \\ (e-mail: akhmaduncen@gmail.com)
}

\begin{abstract}
This article reveals the dynamics of local communities in Papua in accommodating differences between them. Those different ethnic and cultural communities, are able to build social relations through cultural mechanisms. Using the ethnographic approach this article reveals that Papuan people have a strong cultural capital to relate existing differences. Through communal culture, exchange relation in the form of enjoying eating together, religion of relatives, and the culture of one stone stove made of three stone, as well as inter-clans marriage become the mechanism that becomes elements of social glue between the community members. Although tribal conflicts often occur, traditional communities have a way of handling conflict through cultural mechanisms, such as "eating together", "burning stones" and accompanied by slaughter of sacrificial animals.
\end{abstract}

Artikel ini mengungkapkan dinamika komunitas-komunitas lokal di Papua dalam merajut perbedaan diantara mereka. Komunitas etnik dan budaya yang berbeda, mampu membangun relasi sosial lewat mekanisme budaya. Dengan menggunakan pendekatan etnografi terungkap bahwa masyarakat Papua memiliki modal budaya yang kuat dalam merajut perbedaan yang ada. Lewat budaya komunal, relasi pertukaran dalam wujud makan bersama, agama bersaudara, dan budaya satu tungku tiga batu, serta budaya perkawinan antar klan atau marga merupakan mekanisme yang menjadi unsur-unsur perekat sosial diantara mereka. Meskipun konflik antar suku kerap juga terjadi, namun komunitas-komunitas adat memiliki cara penanganan konflik melalui mekanisme budaya, seperti "makan bersama", "bakar batu" dan disertai dengan pemotongan hewan kurban.

Keywords: Papua; community; religion of relatives; handling conflict 


\section{Pendahuluan}

Membicarakan Papua dalam konteks "kebinekaan" jika dibandingkan dengan wilayah-walayah lain di luar Papua, maka tidaklah berlebih kalau dikatakan bahwa Papua adalah spektrum dari harmoni di tengah keragaman. Berada pada gugusan kepulauan Melenesia dengan tingkat keanekaragaman sosial budaya yang sangat majemuk. Hasil penelitian SIl (Summer Instut of Languages) telah mengidentefiksi lebih dari 250 bahasa yang ada di Papua yang tersebar ke dalam 7 wilayah kebudayaan yaitu, Mamanta/Tabi, Saireri, Doberai, Bomberai, Anim Ha, Lapa go, Me Pago. ${ }^{1}$

Meski banyak bahasa yang ada, tetapi bahasa Indonesia sudah digunakan oleh hampir semua suku di Papua sebagai lingua franca. Kebinekaan sukubangsa di Papua tersebut tercermin dalam berbagai unsur budaya seperti bahasa, struktur organisasi sosial, sistem kepemimpinan,

${ }^{1}$ Mamta, meliputi Port Numbay, Sentani, Genyem, Depapre, Demta, Sarmi, Bonggo, Mamberamo. Wilayah adat Saireri, termasuk Kepulauan Biak Numfor, Supiori, Yapen, Waropen, Nabire bagian pantai. Wilayah adat Domberay antara lain Manokwari, Bintuni, Babo, Wondama, Wasi, Sorong, Raja Ampat, Teminabuan, Inawantan, Ayamaru, Aifat, Aitinyo. Wilayah adat kawasan Bomberay meliputi Fakfak, Kaimana, Kokonao dan Mimika. Wilayah adatkawasan Ha Anim, meliputi Merauke, Digoel, Muyu, Asmat dan Mandobo. Wilayah adat kawasan Me Pago, antara lain Pegunungan Bintang, Wamena, Tiom, Kurima, Oksibil, Okbibab. Wilayah adat kawasan La Pago antara lain, Puncak Jaya, Tolikara, Paniai, Nabire pedalaman. agama, dan sistem mata pencaharian hidup berdasarkan ekologi daerah tersebut (Purwanto 2012; Mahsun 2015).

Keadaan geografi dan iklim, menyebabkan terjadinya pola-pola adaptasi yang berbeda-beda antara satu atau beberapa golongan etnik lainnya berdasarkan perbedaan lingkungan ekologi yang menjadi tempat tinggal mereka. Hal ini juga menyebabkan timbulnya perbedaan perkembangan struktur-struktur sosial masyarakat yang juga ditentukan oleh prosesproses adaptasi terhadap lingkungan alamnya. Mereka pun mewujudkan polapola kehidupan yang bervariasi sampai kepada berbeda satu sama lain (Iribaram, 2011).

Dalam perspektif Sumber Daya Alam, Papua sungguh memiliki nilai kehidupan ekonomi, sosial budaya dan ekologis yang tinggi. Di dalam perut bumi Cenderawasih terkandung potensi sumber daya alam yang melimpah-ruah. Mulai dari minyak dan gas bumi (migas), batubara, nikel, tembaga, perak, emas hingga uranium. Wilayah Papua tanah yang diberkati oleh Tuhan. Papua laksana mutiara di kawasan timur Indonesia. Lingkungan alam wilayah terluas di persada Nusantara itu bak kidung agung sebuah orchestra kehidupan alam yang melantunkan syair-syair dan bait yang merdu dan meneduhkan hati, serta gerakan harmonis saling bertautan tentang keindahan, kebesaran dan kemuliaan ciptaan Tuhan di muka bumi ini (Numberi 1996). 


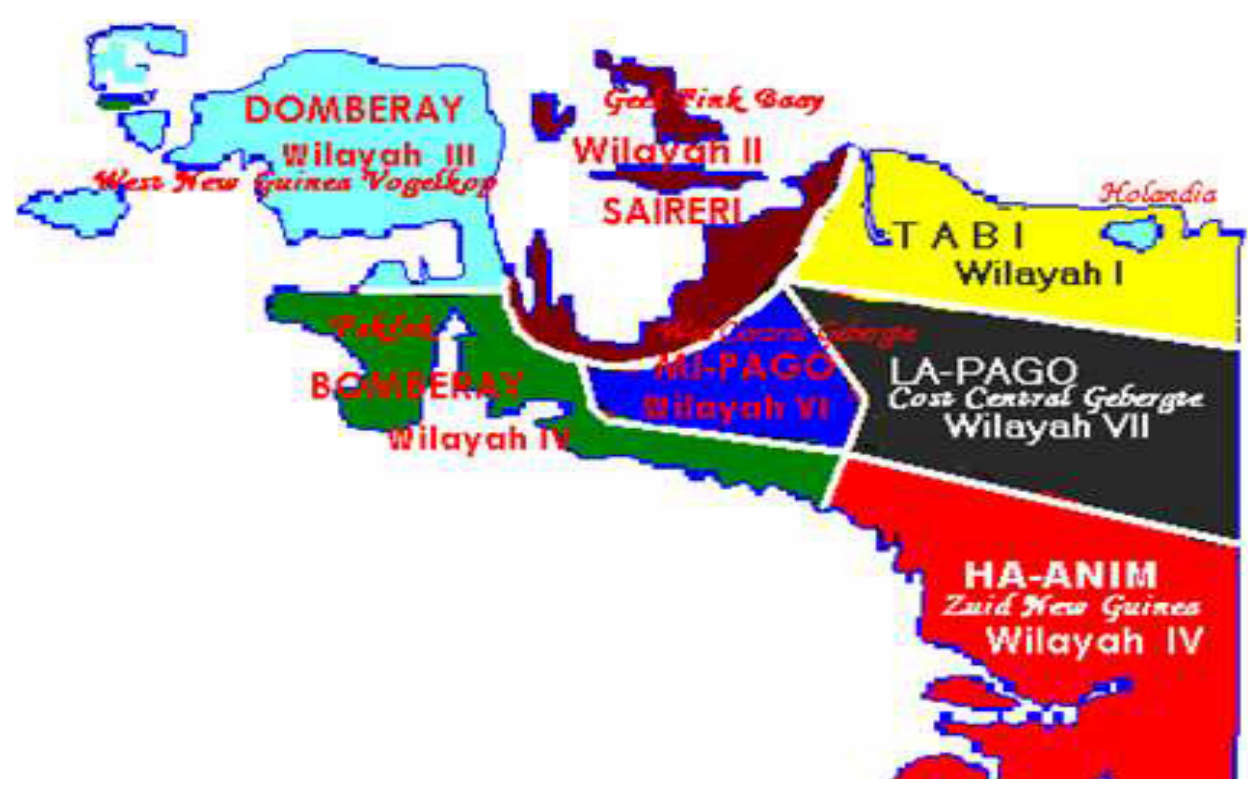

Gambar 1. Peta Wilayah Kebudayaan Papua

Masyarakat Papua adalah masyarakat pluralis, dan di dalam pluralisme tersebut menurut Tilaar (2004: 257) tersimpan kekuatan yang sangat besar yaitu kapital budaya berupa keanekaragaman adat istiadat, kepercayaan, bahasa, dan sistem mata pencaharian. Sebagaimana yang diungkapkan oleh Koentjaraningrat (1970), bahwa penduduk Papua yang hidup di zona ekologi rawa, misalnya orang Asmat dan orang Mimika, bermatapencaharian pokok meramu sagu sedangkan menangkap ikan merupakan mata pencaharian pelengkap. Sebaliknya buat orang Dani dan orang Me yang hidup di zona ekologi dataran tinggi, pertanian merupakan mata pencaharian pokok hidup pada zona ekologi kaki-kaki gunung dan lembah-lembah kecil menjadikan perladangan dan meramu sagu sebagai mata pencaharian pokok disamping berburu dan beternak. Secara spesifik, van Baal (Mansoben, 1995) menunjukkan bahwa kompleksitas sistem ritus dan keagamaan pada orang Papua yang berbeda itu juga dipengaruhi oleh faktor lingkungan alam yang berbeda dan sistem matapencaharian hidupnya. Orang-orang Papua yang hidup di zona ekologi rawa dan muara sungai, pada umumnya menyelenggarakan upacaraupacara keagamaan yang lebih meriah dibandingkan dengan orang Papua yang menkonsumsi umbi-umbian, dan hidup diekologi dataran tinggin seperti pada masyarakat yang hidup di daerah Pegunungan Tengah.

Sebagai masyarakat yang berdiam di gugusan kepulauan Melanesia, kekuatankekuatan keramat mengikat masyarakat baik dalam hubungan kekuasaan maupun 
di dalam berbagai aspek kehidupan lain. Mulai dari adanya kekuatan natural seperti kekuasaan kepala klan sampai kepada kekuatan supernatural yang diturunkan dari satu generasi ke generasi berikutnya. Marshall D. Sahlins (1963), menunjukkan bahwa sistem kepemimpinan masyarakat Melanesia mengacu pada pola orang besar (big man) yang semuanya tampak cenderung borjuis. Perbedaan budaya lokal membuat mereka memodifikasi ekspresi kekuasaannya. Tetapi secara kualitas, memiliki kesamaan yaitu kekuasaan pribadi melalui kemampuan atau pencapaian dari pembangunan hubungan antar personal dalam masyarakat. Dinamika politik masyarakat Melanesia terbentuk dari hasil kompetisi dengan orang lain. Sedikit atau banyak otoritas merupakan pencapaian sosial dengan kata lain kepemimpinan itu sebuah penciptaan, penciptaan pengikut. Sementara itu, Mansoben (1995) mengelompokkan lima pola kepemimpinan tradisional, yaitu: 1) sistem pemerintahan adat dengan tipe kepemimpinan pria berwibawa; 2) Sistem pemerintahan adat dengan tipe kepemimpinan raja; 3) sistem pemerintahan adat dengan tipe kepemimpinan kepala suku atau kepala klan; 4) sistem pemerintahan adat dengan tipe kepemimpinan campuran.

Orang-orang Papua telah melintasi sejarah yang panjang dan berliku hingga perjumpaan mereka dengan dunial luar. Pengaruh-pengaruh agama Islam, Kristen,
Budha, dan Hindu, serta kekuatankekuatan politik (kolonialisme), ekonomi, telah mempengaruhi fragment-fragment kebudayaan lokal di Papua. Meskipun demikian, ada kencenderungan yang kuat bahwa kepentingan dan perkembangan penduduk Papua terrmarjinalkan oleh penerapan skenario pembangunan yang tidak sensitif dengan sejarah dan karakter asli masyarakat Papua (Himam, 2015). Searus dengan itu, Yulia Sugandi (2008), mengungkapkan bahwa Identititas kolektif orang Papua sebagai sebuah masyarakat yang modern dan beradab cenderung dipaksakan melalui program dari luar. Maka, apa yang terjadi kemudian adalah terjadinya lopotan kultural pada komunitas-komunitas asli melalui proses akulturasi budaya yang sifatnya mendadak antara Penduduk Asli Papua dengan kebudayaan-kebudayaan dari luar yang berdampak pada kehidupan sosial kultural orang Papua.

Sebagai suatu entitas kultural, orangorang Papua telah mengalami mobilitas kultural dengan mengapropriasi simbolsimbol budaya melalui proses akulturasi, dan ini mengisyaratkan bahwa orang Papua bukanlah entitas tunggal yang terkungkung dalam adat istiadat, melainkan sangat dinamis dan telah mengalami perubahan. Sekarang kita dapat melihat bahwa reaksi orang-orang Papua baik yang tinggal dipelosok pedesaan sampai perkotaan tidak sekedar pasif, mereka tidak kedap dari pertukaran peradaban, 
seperti migrasi, gaya hidup, konsumsi, dan perubahan ekonomi. Jaap Timmer (2007: 623) misalnya, menunjukkan bahwa sepanjang sejarah, komunitas lokal di Papua menjadi subjek bagi aneka bentuk distabilitas sebagai akibat dari interaksi dengan orang-orang lain dan mereka secara kontinu mengembangkan strategistrategi baru dengan semangat inventif lokal. Sejak berabad-abad yang lalu, Papua sudah dihuni oleh banyak komunitas yang beragam, baik komunitas "asli" maupun "kaum pendatang". Papua seperti tanah lain di Nusantara, telah terhubungan dengan dunia luar sejak awal ke-19. Para pedagang dan armada perang telah berhubungan dagang, perkawinan dan membangun kekuatan politik. Interaksi dengan dunia luar sejak dahulu kala telah memberi bangunan dasar keberagaman dan kosmopolitasnime.

Penduduk Papua adalah contoh terbaik dari sebuah peradaban mengenai kehidupan yang humanis dan toleran. Papua tampil menjadi pemersatu antar semua golongan, etnis, dan agama. Salah satu keunggulan dari komunitas-komunitas di Papua adalah keterbukaan pada semua entitaskultural dan mereka mampu menerima, mengakui, dan menghormati perbedaan. Kelompok-kelompok etnik dan budaya Papua tersebut memiliki daya pegas untuk memelihara identitas kelompoknya dan pada kutub yang lain mampu berinteraksi dalam ruang bersama dan bersedia untuk menerima perbedaan.
Dalam fenomena budaya seperti ini, Laksono (2009) menunjukkan, meskipun komunitas tempatan tersebut telah diterpa berbagai arus ide dan adat istiadat, tradisi lokal mereka masih tetap bertahan dan sangat dominan. Warna kebudayaan mereka sangat kuat mempegaruhi hampir semua sendi-sendi kehidupan. Dalam proses seperti itu, Laksono (2009) menunjukkan bahwa "warna" tempatan menjadi kuat bertahan karena masyarakatnya, terutama para elitnya berhasil mengidentifikasi dirinya dalam proses tersebut. Mereka pun mampu mengolah atau mengambil alih budi bahasa "asing" justru untuk melestarikan ketidaksetaraan sosial tradisionalnya daripada ikut tersamaratakan oleh gelombang pengaruh budi bahasa dan gaya hidup baru. Tulisan ini ingin menujukkan sebuah potret lain dari belahan timur Indonesia, ketika ditempat lain muncul sikap radikal, yakni bentuk penolakan terhadap pluralitas meskipun pluralitas merupakan suatu keniscayaan yang tidak bisa kita hindari. Secara rinci tujuan dari artikel ini adalah untuk mengungkap beberapa mekanisme budaya orang Papua untuk membangun relasi sosial, yaitu: relasi pertukaran, agama bersaudara, dan budaya satu tungku tiga batu.

\section{Kehidupan Komunal}

Setiap komunitas atau kelompok sosial biasanya memiliki cara dan mekansime dalam menyikapi persoalan sehari-hari, mulai dari persoalan yang paling nyata 
seperti pemenuhan sandang pangan hingga pada penyelesaian konflik yang terjadi di antara anggota-anggotanya. Pengelolaan kehidupan kolektif ini telah dipraktekkan orang-orang Papua sejak lama, sebelum ada campur tangan dari pihak luar. Komunitas-komunitas tersebut biasanya mengandalkan hubungan dan pranata-pranata informal serta aturanaturan tidak tertulis yang sudah berproses secara turun-temurun. Menurut Abdullah (2015: 260) berbagai bentuk institusi lokal telah ditumbuhkan oleh masyarakat dari waktu ke waktu yang bersifat adaptif terhadap berbagai persoalan ekologis, sosial, politik, dan ekonomi. Institusi lokal dapat berupa kelembagaan atau prantapranta sosial yang berfungsi dan berperan secara langsung maupun tidak langsung .

Menurut Elmberg (Mansoben 1995: 93), pengertian klan adalah suatu kesatuan sosial yang menggunakan nama yang sama menurut keyakinannya bahwa mereka berasal dari nenek moyang yang sama serta seringkali mempunyai keyakinan terhadap roh-roh yang sama dari orangorang yang telah meninggal. Dari sanalah kemudian dibangun konsep komunitas, yaitu rasa identitas komunal yang mempunyai sejarah, tradisi yang relatif sama berelemen utama kebudayaan yang mendiami suatu unit geografis berdasarkan identifikasi atau disepakati bersama.

Dalam narasi sosial Papua, memperlihatkan begitu banyak pengetahun lokal di
Papua yang mampu memberikan pengaruh terhadap kelangsungan hidup orang Papua sebagai identitas budaya atau jati diri orang Papua. Di dalam sistem organisasi sosial orang Papua misalnya, mereka yang bermukim di wilayah zona ekologi muara sungai, pesisir pantai, kita jumpai penduduk yang hidup dalam keluargakeluarga inti kecil (rata-rata 4 sampai 5 individu). Keluarga inti ini hidup secara otonom yang bersifat individualistis. Meskipun hidup dalam rumah tangga dan keluarga inti yang otonom, mereka masih memiliki sentimen kolektif yang sangat kuat. Hal seperti ini terlihat kehidupan yang sangat komunal, misalnya pembagian hasil-hasil kebun, hasil memancing dan berburu di hutan didistribusikan pada keluarga-keluarga lain, tetangga dan kerabat dekat. Contoh masyarakat seperti ini adalah penduduk pantai utara (Koenjaraningrat 1970). Kegiatan sosial dan ritual-ritual seperti kelahiran, kematian, perkawinan merupakan bagian yang tak terpisahkan dari kegiatan budaya dalam rangka memperkuat relasi sosial dalam masyarakat. Hubungan-hubungan resiproisitas diaktifkan sedemikian rupa sehingga terjadi sentimen sosial di antara masyarakat pendukung kebudayaan tersebut. Beda lagi dengan mereka yang bermukim di wilayah zona ekologi Pegunungan Tengah, kita jumpai penduduk yang hidup dalam rumah-rumah besar dalam hubungan-hubungan keluarga luas. 
Mereka memiliki jaringan luas dari sistem klan, gabungan klan dan federasi yang kompleks, contoh penduduk seperti ini adalah Suku Dani yang bermukim di Lembah Baliem Wamena. Haviland (1985) menjelaskan bahwa proses adaptasi seperti ini menghasilkan keseimbangan yang dinamis antara kebutuhan penduduk dan potensi lingkungan.

Salah satu unsur budaya yang membingkai solidaritas kelompok komunitas di Papua adalah kehidupan komunal. Dalam kesatuan sosial yang paling pentingadalah kesatuan keluarga inti monogami sebagai kelompok kekerabatan yangpaling dekat dengan kaum kerabat yang lain. Kekerabatan yang lebih luas dari keluarga inti adalah klan atau marga. Pertalian hubungan kekerabatan ini termasuk mekanisme terpenting yang memperkuat solidaritas internal dalam komunitas pada sebuah komunitas. Relasi saling membantu (resiprositas) dan saling memberi bantuan adalah hal yang paling istimewa dalam kehidupan komunal. misalnya pembagian hasil-hasil kebun, hasil memancing, dan hasil berburuan akan didistribusikan pada keluarga-keluarga inti, keluarga luas, dan tetangga. Bahkan dalam kehidupan komunal ini antara hak kepemilikian pribadi dan hak komunal sangat tipis perbedaannya. Suatu kerabat dengan seluruh warga anggotanya adalah satu kesatuan fungsional baik secara sosial dan ekonomi.
Sebagai suatu daerah yang terletak pada gugusan kepulauan Melanesia, maka polapola kekerabatan pada masyarakat di Papua menganut pola kekerabatan patrilineal, yang memperhitungkan hubungan keturunan berdasarkan pertalian menurut garis keturunan pihak laki-laki. Kajian van Wouden (1985) yang mengkaji mengenai klan, mitos dan kekuasaan telah membuka tabir tentang bentuk-bentuk kehidupan (kebudayaan) di kepulauan Indonesia bagian Timur. Van Wouden menunjukkan bagaimana konsep klan dan pola perkawinan cross-cousins yang eksklusif mempengaruhi alam berpikir dan cara pengorganisasian masyarakat di belahan Indonesia bagian Timur. Menurut Elmberg (Mansoben, 1995: 93), pengertian klan adalah suatu kesatuan sosial yang menggunakan nama yang sama menurut keyakinannya bahwa mereka berasal dari nenek moyang yang sama serta seringkali mempunyai keyakinan terhadap roh-roh yang sama dari orang-orang yang telah meninggal. Dari sanalah kemudian dibangun konsep komunitas, yaitu rasa identitas komunal yang mempunyai sejarah, tradisi yang relatif sama berelemen utama kebudayaan yang mendiami suatu unit geografis berdasarkan identifikasi atau disepakati bersama. Mereka hidup berkelompok dalam klan atau marga dan secara ketat menjalankan ketentuan eksogami klan. Pola-pola kekerabatan mereka menganut pola kekerabatan patrilineal, yang memperhitungkan hubungan ke- 
turunan berdasarkan pertalian menurut garis keturunan dari pihak laki-laki. Keluarga keluarga inti kecil sebagai kelompok kekerabatan yang paling kecil dan keluarga inti tersebut hidup secara otonom yang bersifat individualistis. Sementara itu, kekerabatan yang lebih luas dari keluarga batih adalah klan.Meskipun hidup dalam rumah tangga dan keluarga inti yang otonom, mereka masih memiliki sentimen kolektif yang sangat kuat. Hal seperti ini terlihat kehidupan yang sangat komunal, misalnya pembagian hasil-hasil kebun, hasil memancing dan berburu di hutan didistribusikan pada keluarga-keluarga lain, tetangga dan kerabat dekat. Kegiatan sosial dan ritual-ritual seperti kelahiran, kematian, perkawinan merupakan bagian yang tak terpisahkan dari kegiatan budaya dalam rangka memperkuat hubungan sosial dalam masyarakat. Hubunganhubungan resiprositas diaktifkan sedemikian rupa sehingga terjadi sentimen sosial di antara masyarakat pendukung kebudayaan tersebut. Solidaritas sosial dalam lingkup klan sangat kuat untuk saling memberi bantuan dari aktivitas sosial yang melibatkan keluarga inti dan klan. Dalam hal perkawinan misalnya, kerabat patrilineal sangat dominan, seorang laki-laki yang akan menikah akan mendapat bantuan dari kerabat ayahnya. Masyarakat di wilayah ini mengenal keluarga batih sebagai kelompok kekerabatan yang paling kecil. Kekerabatan yang lebih luas dari keluarga batih adalah keret (fam). Beberapa keret/fam bergabung dalam satu mata rumah yang memiliki nenek moyang yang sama mengikuti garis keturunan patrilineal. Solidaritas sosial dalam lingkup keret/fam sangat kuat untuk saling memberi bantuan dari aktivitas sosial yang melibatkan keret/fam. Dalam hal perkawinan misalnya, seorang laki-laki yang akan menikah akan mendapat bantuan keret/fam dari kerabat ayah.

Dalam kehidpan komunal terdapat mekanisme dalam pengelolaan sumber daya tanah. Umumnya orang-orang Papua mengenal dua pola penguasaanatas tanah, yakni kepemilikan individu (pribadi) dan kepemilikan secara komunal. Hak kepemilikan komunal, yaitu hak yang dimiliki, dikuasai, dimanfaatkan, dinikmati, dan dikelola oleh sekelompok manusia yang hidup dalam suatu wilayah tertentu yang disebut dengan masyarakat hukumadat. Kepemilikan yang disertai dengan batas kewenangan atas wilayah sumber daya tanah tersebut berasal dari konsensus para nenek moyang mereka melalui pola pewarisan kepada generasi berikutnya mengikuti garis kekerabatan patrilineal. Ini berarti bahwa hak waris jatuh kepada anak laki-laki. Penggunaan tanah hak ulayat untuk pemukiman atau pun untuk keperluan ekonomi biasaya tidak pernah dipermasalahkan asalkan terlebih dulu meminta izin kepada klan pemilik hak ulayat. 
Sama seperti masyarakat pemburuperamu, masyarakat peladang memerlukan ekosistem -dalam hal ini adalah hutan- yang luas, dimana pemanfaatan hutan tersebut diatur oleh sistem kepemilikan lahan secara komunal yang lazim disebut sebagai "hak ulayat". Pengakuan atas hak ulayat komunal ini selain dikukuhkan melalui pranata-pranata sosial yang berkaitan dengan pengaturan sumber daya alam di dalam lingkup masyarakat itu, juga dikukuhkan melalui kesepakatan dengan antar masyarakat pendukung hak ulayat lain di sekitar mereka. Substansi dari pengakuan atas kepemilikan lahan atau hak ulayat ini adalah penguasaan atas sumber daya alam, terutama yang menghasilkan bahan makanan untuk kelangsungan hidup komunal.

Kehidupan Komunal biasanya dilatari dengan berbagai persoalan sosial kultural yang dihadapi oleh setiap komunitas. Fakta-fakta etnografis tentang Papua menunjukkan bahwa komunitas lokal Papua mengembangkan kehidupan mereka lewat berbagai relasi sosial, persaingan, bahkan didahului olek konflik sosial. Selain itu, tragedi kemanusiaan seperti kelaparan, penyakit, perang antar suku, ikut mendorong lahirnya sentimen sosial. Sebagai contoh yang digambarkan oleh Samaduda dan Baiquini (2000: 95), bahwa perkampungan terbentuk sekarang ini, didasarkan pada praktik perang suku pada masa lalu terkait dengan penaklukan suatu wilayah ke- kuasaan. Akibat dari perang antar suku, terjadi migrasi penduduk yang hidupnya terancam dan mencari perlindungan di wilayah-wilayah yang dianggap aman untuk dihuni. Mereka kemudian membentuk komunitas-komunitas kecil dan membangun unit-unit perkampungan kecil di tempat yang baru. Dalam proses selanjutnya, muncul aliansi-aliansi akibat hubungan perkawinan antar dua moyang, perjanjian-perjanjian antar kelompok dan akibat perasaan senasib ketika mereka berimigrasi. Oleh karena itu, kecenderungan yang terjadi adalah mereka hidup berkelompok dalam balutan budaya komunal. Pengelompokan ini didasarkan pada bagaimana mereka mempertahankan hidup dengan solidaritas komunal. Faktafakta etnografis dan catatan sejarah seperti ini dapat memberikan kita sebuah kesimpulan bahwa dulu sebelum ada campur tangan kekuatan-kekuatan dari luar seperti negara, agama, kekuatan modal global, komunitas-komunitas adat/tempatan sebenarnya sudah punya mekanisme dalam menyelesaikan persoalan hidup mereka sehari-hari dengan mengebangkan apa yang disebut sebagai kearifan lokal.

\section{Relasi Pertukaran}

Meskipun ada jarak yang memisahkan antara komunitas yang satu dengan komunitas lainya karena perbedaan kondisi lingkungan alam dan sosial budayanya, namun demikian mereka tetap mem- 
bangun relasi-relasi pertukaran antara satu komunitas dengan komunitas lainnya melalui jalur perdagangan atau pertukaran tradisional. Perdagangan dengan cara barter atau pertukaran langsung masih dijumpai model pertukaran tradisional yang melandasi sistem sosial orang Papua. Pertukaran bukan saja pada barang, seperti ubi ditukarkan dengan garam, tetapi juga pertukaran dapat terjadi antara istri-istri dari dua kelompok. Menurut Muller (2009: 126-127), perdagangan pada masyarakat pegunungan dipercaya bisa membawa perdamaian, melalui hubungan kekerabatan (saudara ipar), karena pernikahan dengan pihak di luar kekuasaan klan akan membuka peluang perdagangan dan perdamaian. Selain itu kawin di luar klan (atau marga) memiliki makna yang lebih luas memperluas jaringan sosial politik, perdagangan, kekerabatan dan penyatuan komunitas.

Gejala pertukaran tradisional atau barter di Papua dapat dilacak dari karya etnografi Bronislaw Malinowksi tentang perdagangan kula di kepulauan Trobiand di sebelah tenggara Papua. Perdagangan tradisional seperti itu terjadi pula di wilayah Kepala Burung khususnya pada orang Maibrat (Meibrat, Meybrat), orang Madik, dan orang Karon, yang memperdagangkan kain timur. Fungsi kain timur adalah sebagai pembayaran mas kawin, pembayaran denda, dan upacara kematian (Koentjraningrat dan Sanggenafa 1993).
Menurut Elbert (dalam Mansoben 1995: 94), pada waktu lampau kain timur ${ }^{2}$ atau bo berperan sebagai alat bayar atau tukar, jadi berfungsi sebagai uang.

\section{Pada masyarakat Me di Pegunungan} Tengah Papua, pertukaran tradisonal bersinggungan dengan upacara pesta babi. Transaksi perdagangan antarindividu atau antarkelompok terjadi pada saat pesta babi berlangsung (Pospisil 1963). Seorang tonowi atau orang kaya pada orang $\mathrm{Me}$ adalah seseorang yang secara individual berhasil mengumpulkan banyak uang atau "mege" berupa kulit kerang, memiliki banyak babi, banyak istri, dan banyak

\footnotetext{
${ }^{2}$ Masuknya kain timur ke wilayah "Kepala Burung" dan pantai barat Papua dapat ditelusuri sejarahnya dari Pires dan Haga seperti berikut: 'Pada awal abad ke-16 Pati Cucup (Pati Usuf), Raja Grisee (Gresik) di pantai utara pulau Jawa, melakukan perdagangan dengan kepulauan Maluku dengan menggunakan kapal-kapalnya sendiri. Rute perjalanan kapal-kapal Pati Usuf ke Kepulauan Maluku dan Banda itu melewati pulau-pulau Bali, Lombok, Sumba, dan Bima. Dari pulau-pulau itu pedagang Gresik membeli kain-kain yang berkualitas kurang baik bila dibandingkan dengan kain patola yang berasal dari Gujarat, Inidia, yang diperdagangkan di Jawa untuk kemudian dijual di Banda dan kadang di kepulauan Kei. Aru, dan Seram. Selanjutnya Banda memperdagangkan kain yang berkualitas kurang baik untuk memperoleh budak, sagu, dan kulit massoi dari Ambon, Ternate, Kei, Aru, dan Seram. Dari Seram kain-kain tersebut dijual kepada penduduk pantai Kepala Burung Papua. Melalui penduduk pantai inilah kain timur masuk ke daerah pedalam Kepala Burung. Penduduk pantai membawa kain ke daerah Meibrat untuk menukarkannya dengan budak. Di samping itu kain yang berasal dari luar itu di bawa ke daerah Meibrat oleh para pemburu cenderawasih. Kain yang berasal dari luar inilah yang kemudian dikenal di daerah Meibrat dengan nama kain timur (Mansoben 1995: 98-99).
} 
pengutangnya (Mansoben 1995: 120). Demikian pula yang terjadi pada masyarakat Dani di Lembah Baliem Wamena, Karel G. Heider (1970) mencatat gerakan barang dalam jaringan sosial orang Dani didasarkan pada empat faktor, yaitu pemberian kepada teman dekat dan tetangga; upacara adat; perdagangan; dan pembayaran denda. Orang Dani mengenal sistem perdagangan antara kelompok konfederasi yang biasa dilaksanakan lewat suatu upacara pesta babi dengan menggunakan kulit kerang sebagai alat tukar (Mansoben 1995: 161). Pada masyarakat pegunungan Papua, uang berbentuk keping-keping kulit kerang (cowrie) yang diberi nilai tertentu. Sekarang ini mata uang resmi yang dikeluarkan oleh bank sudah menggantikan kepingan cowrie (Muller 2009: 126).

Meskipun mereka juga memelihara babi, namun babi hanya dimakan pada saat tertentu seperti pesta adat. Pada saat perayaan pesta adat, babi dikorbankan kepada arwah para leluhur, dan daginnya dimakan dalam upacara adat oleh orangorang yang ikut serta dalam upacara ter sebut. Peristiwa seperti ini bukan saja memberi jaminan tersedianya protein hewani yang berkualitas bagi para peserta upacara, tetapi juga penuh dengan motif simbolik, mengorbankan babi adalah peristiwa komunikasi politik, bahwa dengan mengorbankan banyak babi, pesan politik yang ingin disampaikan, bahwa pelakunya adalah orang kaya, orang besar (big man) yang memilik sumber daya yang dapat diredistribusikan kepada banyak orang. Redistribusi ini merupakan gerakan appropriasi yang bergerak dari orang besar dan didistribusikan kembali ke pengikut. Sejak dahulu, babi merupakan bintang peliharaan yang sangat penting bagi Suku Dani. Setiap rumah tangga memiliki peliharaan babi, namun yang dominan mengurusi babi adalah kaum perempuan dan anakanak. Menurut Mansoben (2005: 142143):

"Babi sangat penting dalam kehidupan orang Dani karena mempunyai banyak fungsi, antara lain daginnya dimakan, darahnya digunakan dalam magi, tulangtulang-tulang dan ekornya dibuat menjadi ornament, tulang rusuknya dibuat menjadi pisau untuk mengupas ubi, alat kelaminnya diikat dengan kelang tangan untuk menolak roh-roh jahat dan fungsi yang paling penting adalah penggunaan babi sebagai alat tukar menukar (fungsi ekonomi perdagangan). Selain itu babi dipakai sebagai alat perdamaian dan alat persatuan antara kelompok-kelompok kekerabatan yang berlainan atau antara konfederasi-konfederasi dalam upacara pesta babi yang besar".

Dasar dari pertukaran tradisional seperti kain timur dan kulit kerang pada pesta babi adalah barter dan bersinggungan dengan struktur sosial orang Papua. Semua bentuk perdagangan tradisional ini menekankan pada resiprositas untuk membangun solidaritas yang kuat di dalam kelompok masyarakat. Hubungan resiprositas ini didasarkan untuk men- 
capai kedudukan sosial seorang menjadi pemimpin (big men). Menurut Peter J. Wilson, dalam masyarakat prakapitalis pertukaran harta benda hanyalah suatu simbol dan bukan akhir dari suatu transaksi. Harta benda seperti babi, kulit kerang, ubi rambat, secara umum adalah perantara yang menjadi satu komoditi. Semuanya dapat dirubah ke dalam bentuk komoditi yang berbeda seperti prestise, penghargaan, reputasi, kehormatan, gelar dan tingkat sosial (Wilson 1988: 82). Di sini kemampuan seseorang mengumpulkan harta benda melalui pertukaran tradisional tadi menempatkan seseorang menjadi pemimpin. Mereka yang berhasil sebagai pedagang sejati sajalah yang mempunyai kekuasaan dan pengaruh dalam masyarakatnya (Mansoben 1995: 153). Hal Ini menunjukkan bahwa ekonomi domestik orang Papua tidaklah berdiri sendiri [autonomous], tetapi terekat (embedded) dengan institusi sosial seperti kekerabatan, religi, kepemimpinan atau prestise.

\section{Agama Bersaudara}

Ditengah maraknya intolerasi di belahan Indonesia lainnya,seperti persaingan personal diberbagai lini kehidupan dan pergerakan nilai-nilai konsumtif mendorong kehidupan sosial yang cenderung menuju ke arah sekularisasi. Masingmasing kelompok saling menyindir dan "memaki" serta berusaha mencari pembenaran diri dengan membangun argum- entasi-argumentasi yang sangat subjektif. ${ }^{3}$ Sementara pada akses religius, manusia mengalami konflik secara fragmentarian ${ }^{4}$. Namun beda halnya dengan komunitaskomunitas lokal di Papua. Sebutlah sala satu suku di bagian selatan Teluk Bintuni, yaitu Suku Sumuri. Pada komunitas ini kehidupan beragama orang Sumuri merepresentasikan imajinasi pluralisme yang terdefinisikan dengan cara menyebut agama yang mereka anut sebagai "agama bersaudara". Sekat-sekat agama tidak lagi dipersoalkan dalam konstelasi masyarakat Sumuri, namun justru yang menonjol adalah terbentuknya harmoni dan toleransi di antara umat beragama.

Islam dan Kristen adalah agama bersaudara, demikian informan saya, Pak Saleh seorang imam kampung, mengilustrasikan imajinasi pluralisme yang ditonjolkan oleh orang Sumuri. Pak Bernadus, seorang tokoh agama Kristen Katolik, mengungkapkan pandangan inklusifnya tentang agama bersaudara, yaitu bahwa Islam dan Kristen pada dasarnya sama, menuntun orang untuk menjadi

\footnotetext{
${ }^{3}$ Lihat misalnya penjelasan Toni D. Pariela dalam "Politik Identitas dan Politik Perilaku (Kasus Maluku)." Renai Tahun IX N0 2, 2009. 57-70.

${ }^{4}$ Dalam banyak kasus yang terjadi di Indonesia, seperti konflik agama yang pernah terjadi di Ambon, agama dikonstruksi untuk mempertegas perbedaan dan mengabaikan hubungan-hubungan sosial dan politik sehingga mengakibatkan konflik yang berdarah-darah karena alasan perbedaan keyakinan (Alqadri 1999; Pariela 2009).
} 
lebih baik dan mengikat satu dengan yang lainnya. Pluralisme dalam beragama tidak hanya ditonjolkan dalam bentuk toleransi beragama, tapi lebih jauh dari itu. Perbedaan agama terkadang tidak menghalangi orang untuk kawin campur dengan orang yang berbeda agama. Domaindomain agama juga menjadi cair dalam marga-marga (extended family) dan tidak menonjolkan eksklusivisme agama. Contohnya, ada marga Dorisara yang beragama Kristen dan ada yang beragama Islam. Ada keluarga-keluarga dalam satu marga yang bersaudara kandung tapi memiliki keyakinan agama yang berbeda dan tidak menghalangi hubungan sosial di antara mereka.

Dua kekuatan institusi agama, Islam dan Kristen, selalu lebur dalam hubungan sosial. Bila hari raya agama tertentu tiba maka kegiatan makan bersama dilaksanakan menurut tradisi agama tersebut, umat beragama lain ikut menikmati makanan tersebut, bahkan ikut memberi sumbangan. Dalam pandangan Koentjaraningrat (Mulder 58: 1999), makan bersama yang bersuasana religius-sosial dengan melibatkan tetangga, kerabat, teman adalah suatu ritus pokok untuk mempertahankan dan menjaga tatanan sosial. Tujuan mereka adalah untuk mendapatkan situasi slamet, yang berarti situasi dimana peristiwa akan melalui jalannya yang telah ditentukan dengan lancar dan tak ada sesuatu pun yang tidak akan terdi pada siapa pun.
Mereka lantas bersama-sama. Contoh lain misalnya ada orang yang meninggal dari agama Islam, maka kerabat yang beragama Kristen ikut larut mendoakan dengan tata cara Kristen. Mereka ikut mempersiapkan segala kebutuhan dalam pemakaman. Bukan hanya sekadar datang duduk, melayat, dan mengantarkannya ke kuburan, hari-hari berkabung diwujudkan dalam hubungan resiprositas. Pembangunan gereja selalu melibatkan umat Islam, demikian pula sebaliknya.

Imajinasi pluralisme juga ditonjolkan dalam pemilihan elit-elit kampung. Informan saya, seorang kepala kampung di salah satu kampung, mengungkapkan bahwa dalam pemilihan kepala kampung mereka mengakomodasi dua kekuatan agama yang ada, yaitu Islam dan Kristen. Pemilihan kepala kampung dilakukan dengan cara demokratis, dan apabila yang terpilih adalah dari Islam, maka sekretarisnya diharapkan beragama Kristen. Tidak berhenti di tingkat kampung, domain agama telah merambah sampai pada tingkat politik yang lebih tinggi.

Foto-foto pada gambar 2, 3, dan 4 adalah tiga kontestan Cabub Teluk Bintuni yang bersaing pada Pilkada 2015. Pasangan calon No. 1 menampilkan sosok berkopiah dan berjanggut yang identik dengan simbol Islam. Pasangan calon No. 2 menampilkan sosok yang mengenakan hiasan kepala dari bulu burung cendrawasih yang identik dengan simbol adat. 
Sementara pasangan calon No. 3 tampil dengan jas yang mengesankan mereka "netral" dan mungkin nasionalis. Para kontestan memilih bersiasat (politik) dengan caranya masing-masing. Mereka beradu taktik untuk mencapai hasrat politiknya. Salah satu cara yang dilakukan adalah bersiasat dalam imajinasi pluralisme dengan mengakomodasi dua kekuatan agama besar, Islam dan Kristen. Dengan demikian, institusi agama mengalami politisasi oleh kepentingankepentingan perseorangan, kelompok, dan golongan. Para calon bupati dan wakil

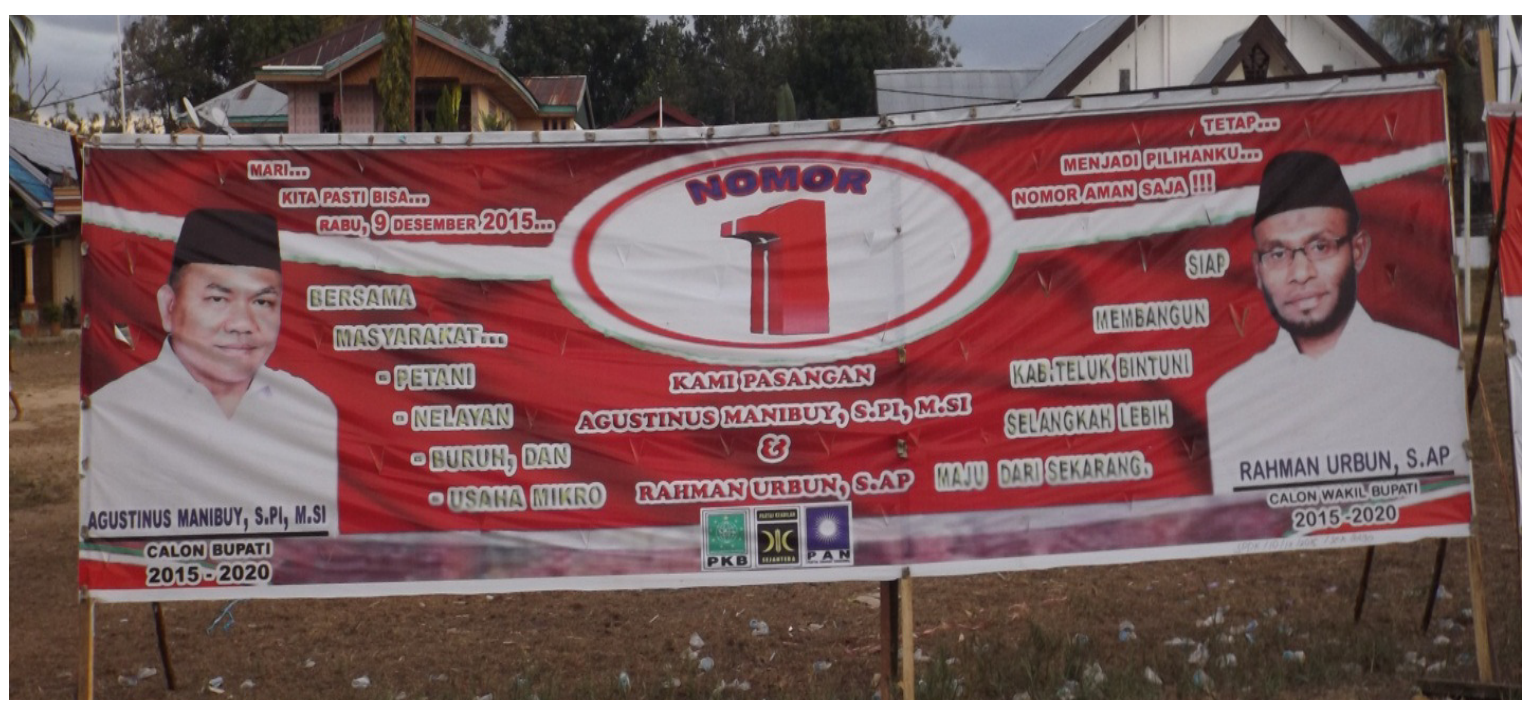

Gambar 2. Paslon Cabup-Cawabup No. Urut 1 Kab. Teluk Bintuni dalam Pilkada 2015.

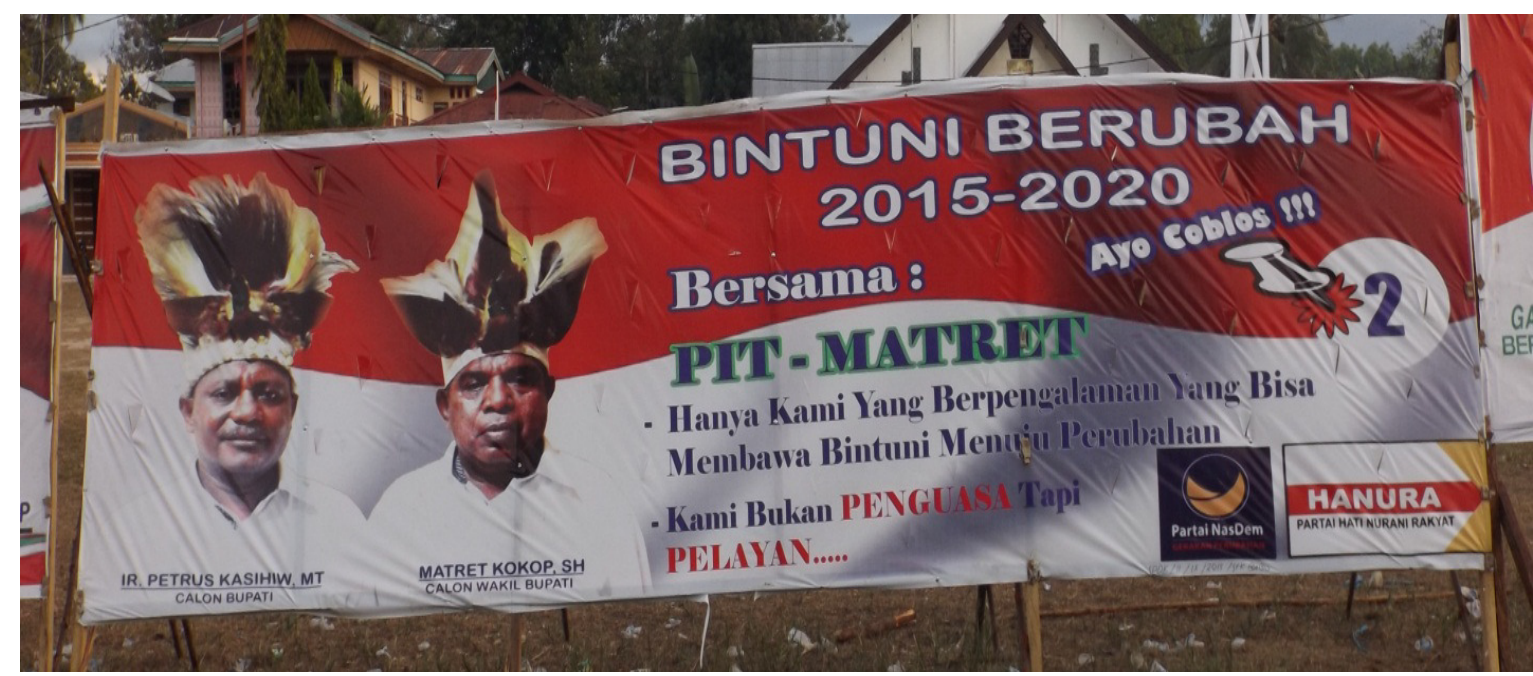

Gambar 3. Paslon Cabup-Cawabup No. Urut 2 Kab. Teluk Bintuni dalam Pilkada 2015. 


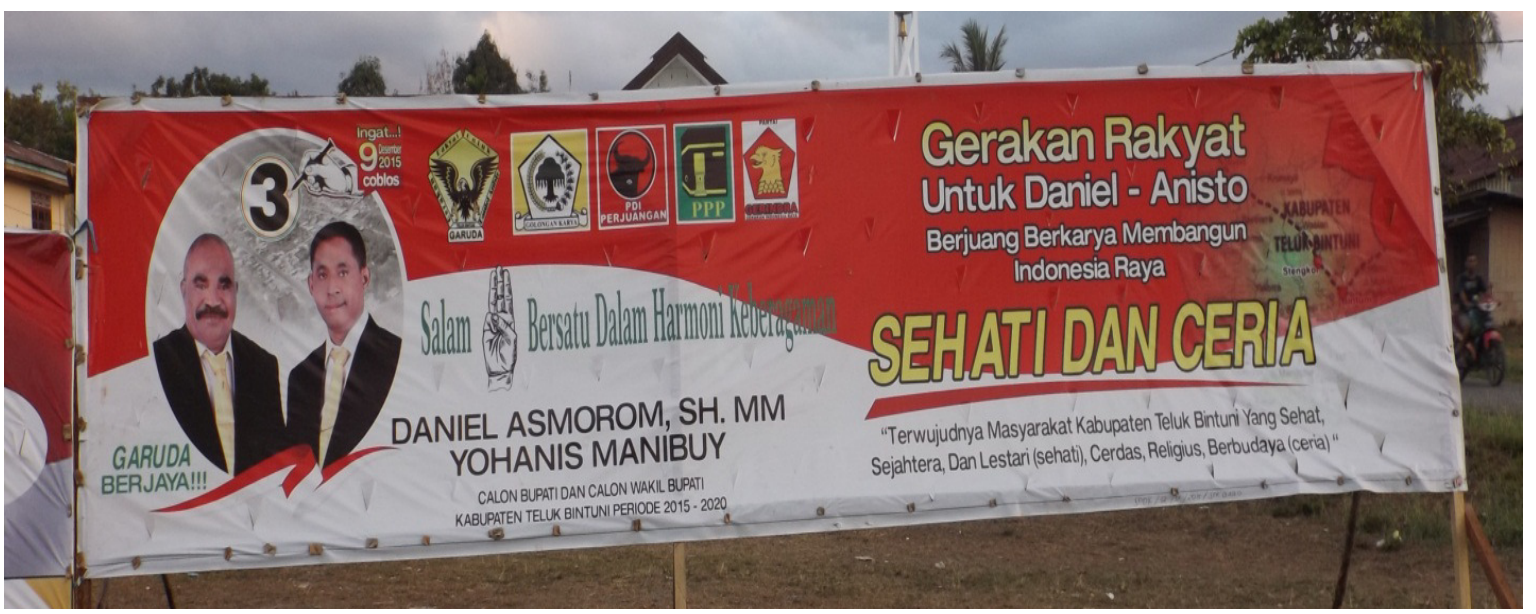

Gambar 4. Paslon Cabup-Cawabup No. Urut 3 Kab. Teluk Bintuni dalam Pilkada 2015.

bupati tersebut kemudian memilih berpasangan dengan orang yang berbeda keyakinan. Dalam kontestasi politik, hal ini dapat dipahami bahwa para warganya, terutama elit-elitnya berhasil mengidentifikasikan dirinya dalam simbol religius dan etnisitas.

Institusi agama menjadi bagian penting dalam pembentukan identitas kultural orang Sumuri dan terus bergerak karena dikonstruksi dari dalam dan di luar orang Sumuri. Secara aktif mereka menciptakan, membentuk, dan memilih atau memberikan respons terhadap hal-hal yang ada di sekitarnya. Dalam konteks ini, dapat dilihat bahwa identitas kebudayaan bisa diubah dan berubah tergantung pada konteks, kekuasaan, dan vested interest yang bermain (Maunati 2004: 31). Konteks kebudayaan seperti ini digambarkan oleh Geertz (1992) sebagai jaring-jaring makna yang dirajut manusia dan sama-sama dimengerti para partisipan sehingga ber- sifat publik atau dalam bahasa Laksono (2009: 35), kebudayaan adalah semua saja yang kita "tahu sama tahu" (TST). Keberadaan agama menjadi sarana yang baik untuk rekonstruksi sosial bagi orang Sumuri. Orang Sumuri bisa mengembangkan kebersamaan melalui acara-acara keagamaan. Dengan demikian agama tidak dimaknai sebagai doktrin atau dakwah, melainkan lebih sebagai ruang hidup berkomunitas.

\section{Budaya Satu Tungku Tiga Batu}

Semangat toleransiantar umat beragama di Indonesia memang masih dalam proses mencari bentuk. Untuk itu sebenarnya banyak modal sosial berupa kearifankearifan lokal hidup rukun di berbagai daerah Indonesia, salah satunya berada di wilayah adat Bomberay bagian selatan tanah Papua, terutama wilayah Fakfak, masyarakatnya mengenal budaya "satu tungku tiga batu". Dalam tulisan itu se- 
lanjutnya disingkat dengan istilah STTB. STTB merupakan sebuah metafora mengenai kehidupan toleransi umat beragama, dengan mengangunakan analogi batu sebagai tungku untuk memasak atau dalam bahasa komunitas setempat disebut "idu-idu manini".

Dalam proses memasak dibutuhkan tiga tungku untuk menjaga keseimbangan agar apa yang dimasak tidak tumpah. Tungku adalah wadah untuk mempersatukan ketiga agama, yaitu Islam, Kristen Katolik, dan Protestan. Istilah STTB ini kemudian dipakai untuk mengekspresikan

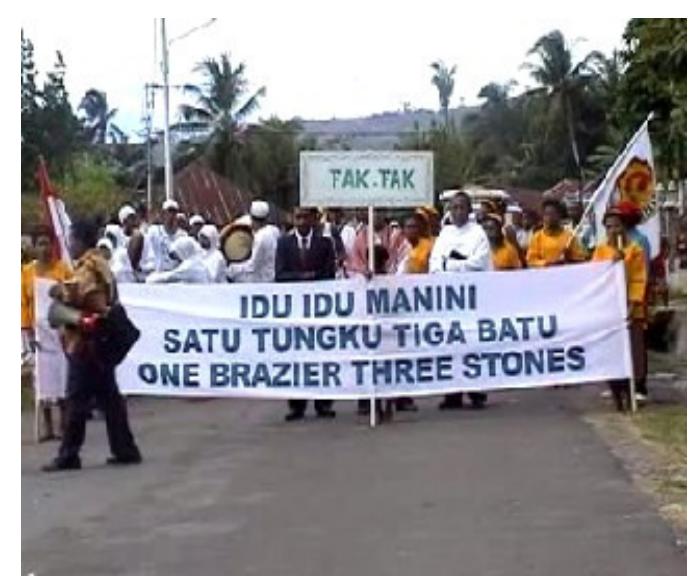

relasi sosial dalam kehidupan beragama, yang maknanya bahwa agama Islam, Kristen Katolik, dan Protestan adalah agama bersaudara. STTB ini kemudian telah ditransformasikan ke dalam energi pembangunan. Sejak beberapa dekade ini, di Papua telah terbentuk pranata pembangunan (pemerintah, agama dan adat), atau semacam kepemimpinan "tiga tungku" yang juga banyak dikenal di daerahdaerah lain. Sebagai sebuah konsep kepranataan, dapat diartikan bahwa untuk menggerakkan pembangunan di Papua, maka ketiga kekuatan tersebut harus bekerjasama dan terkoordinasi.

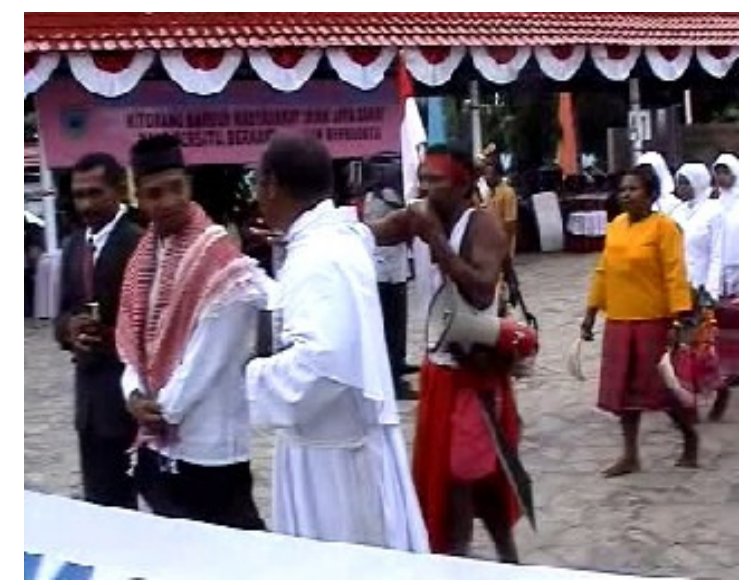

Gambar 5 dan 6 . Perayaan keagamaan yang melibatkan berbagai kelompok agama. Perwujudan budaya "Satu tungku tiga batu" Sumber Gambar: Suparto Iribaram, 2013.

Hadirnya agama dalam sebuah komunitas di wilayah Fakfak tidak ditujukan untuk melakukan diskriminasi terhadap penganut agama lain, melainkan agama menjadi alat perekat antara berbagai kelompok komunitas masyarakat di wilayah Fakfak. Dalam konteks ini, agama dapat dilihat dari dua dimensi, yaitu agama sebagai fenomena teologis, yaitu sebagai ajaran-ajaran berupa muatan- doktrindoktrin yang secara taken for granted harus diterima dan diakui oleh pemeluknya. Sementara, agama sebagai fenomena sosiologis, merupakan pantulan-pantulan 
sosial yang muncul sebagai cermin dari ajaran agama yang diyakininya. Agama bukan saja sebagai sumber kebenaran tetapi juga sumber keteraturan (Nawiruddin dan Malla 2013: 23).

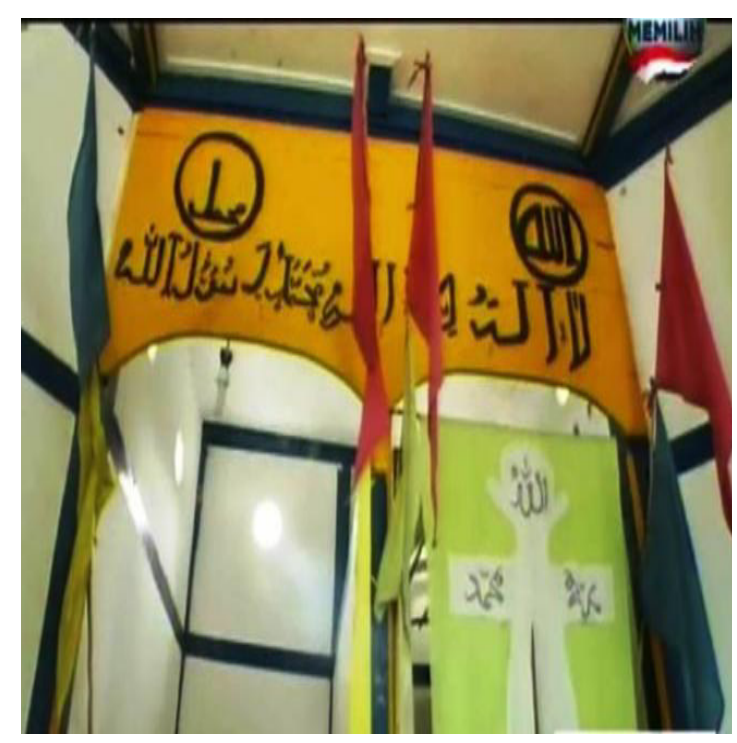

Gambar 7. Masjid dengan nuansa gereja di Patimburak.

STTB (idu-idu manini), istilah ini kemudian dipakai untuk mengekspresikan identitas kultural komunitas di wilayah adat Bomberay, terutama masyarakat Fakfak, yang maknanya adalah bahwa dalam urusan beragama mereka semua bersaudara (imajinasi kolektif), tidak ada sekat-sekat agama yang menghalangi mereka melakukan hubungan-hubungan sosial. Demikian pula pada institusi agama lain seperti Hindu, Budha yang dibawa oleh migran, transmigran, diposisikan sama dengan agama Islam dan Kristen. Institusi agama bukan menjadi ruang privat yang hanya berlaku untuk klan atau marga tertentu. Sudah menjadi rahasia umum "tahu sama tahu" bahwa dalam STTB, agama merupakan moralitas publik, bukan moralitas privat. 5 Emile Durkheim (Nawiruddin dan Malla 2013: 24-25), mengungkapkan bahwa pada hakikatnya agama berfungsi sebagai sumber pembentukan "solidaritas mekanis". Selanjutnya, Durkheim berpendapat bahwa agama adalah satu pranata yang dibutuhkan oleh masyarakat untuk mengikat individu menjadi satu kesatuan melalui pembentukan sistem kepercayaan dan ritus. Lewat simbol-simbol yang sifatnya suci, agama mengikat orang-orang ke dalam kelompok masyarakat.

Semangat STTB tak hanya dalam wacana simbol, tetapi filosofi itu sudah menjiwai perilaku kolektif masyarakat. Dalam hidup berkomunitas misalnya. Suparto Iribaram (2013) menceritakan bahwa:

Pada perayaan hari besar keagamaan seperti hari besar Islam dan Kristen sering dilakukan di Teluk Patipi. Perkampungan yang mayoritas Islam di kawasan itu sering diundang dalam perayaan Natal, pada saat pelaksanaan malam kudus di salah satu gereja di kampung Degen semua orang yang datang memenuhi undangan bukan saja dari kalangan Kristen tetapi juga dari masyarakat yang ada di perkampungan Islam. Malam itu tepat pukul 07.00 WIT semua warga kampung Degen dan tamu yang diundang mulai memasuki gereja dan prosesi dimulai. Semua undang-

Istilah moralitas publik dan moralitas privat, saya pinjam dari Zuhairi Misrawi (2009). 
an yang mengikuti jalannya perayaan natal dan disaat pembakaran lilin, pemuka agama Kristen memberikan penghormatan kepada tokoh adat serta pemuka agama Islam untuk membakar lilin natal.Wanita dari kampung Islam terlibat menyiapkan menu santapan malam setelah perayaan.

Kebiasaan hidup saling menghormati dipraktekkan dalam kehidupan sehari-hari mereka sebagaimana hal yang di tunjukan oleh warga yang berada di perkampungan Kristen mereka sangat menghormati saudaranya yang beragama Islam. Hal ini terlihat ketika kunjungan keluarga Muslim ke rumah keluarga Kristen dalam pelayanannya disediakan wadah yang khusus untuk menyuguhkan makanan dan minuman. Pengetahuan tentang makanan yang tidak diperbolehkan dalam Islam telah diketahui sehingga mereka menyimpan wadah yang pernah digunakan mengolah makanan yang diharamkan dan menggunakan wadah baru. Kerja sama antar umat beragama juga terlihat ketika pembangunan rumah ibadah dan fasilitas umum lainnya dilakukan secara bergotong-royong yang dilandasi nilai-nilai kebersamaan dan kekeluargaan yang dijunjung tinggi.

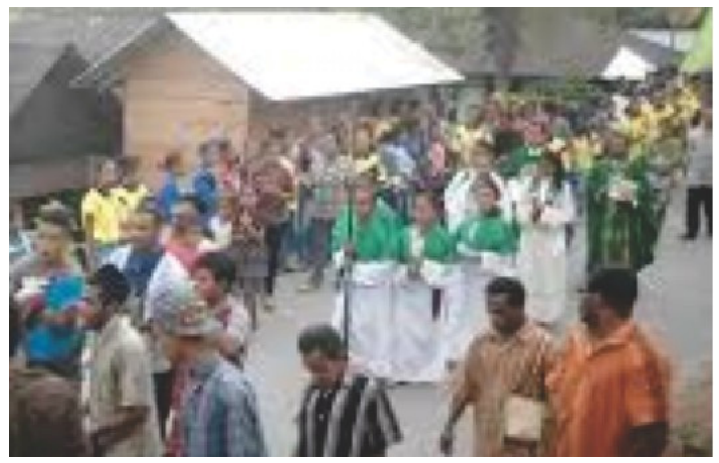

Gambar 8. Sebuah pawai budaya. Sumber: Kompasiana.com

Bila merunut kebelakang, maka pengaruh agama Islam di wilayah adat
Bomberay tidak bisa dilepaskan koopotasi kesultanan Tidore atas pesisir utara pada abad ke-16. Ketika wilayah Papua menjadi bagian dari kekuasaan Kesultanan Tidore, armada-armada hongy dikerahkan untuk memungut pajak berupa hasil hutan dari penduduk pantai (Bachtiar 1992: 49). Dalam rangka mengumpulkan upeti yang lebih besar maka Kesultanan Tidore memperluas wilayah kekuasaannya sampai wilayah timur mencakup pesisir utara Pulau Seram, Gorong, dan Seram Laut dan ke selatan mencakup pesisir barat Papua dan Kepulauan Raja Ampat(Rahman et.al., 2007). Bahkan Kepulauan Raja Ampat disebut sebagai pintu gerbang yang menghubungkan orang Papua dengan pengaruh Kesultanan Tidore. Selain mengumpulkan upeti mereka juga menyebarkan agama Islam dan sejak saat itulah penduduk asli Papua di pesisir pantai utara Papua mulai mengenal ajaran agama Islam dan menyebar di daerah-daerah pesisir pantai. Tampak bahwa penduduk asli Papua yang memeluk agama Islam ada di bagian utara Kepala Burung mulai dari Kepulauan Raja Ampat, Fakfak, Kaimana sampai ke Teluk Bintuni.

Beda halnya dengan agama Kristen. Masuknya agama Kristen di Papua tidak dapat dilepaskan dari sejarah pendudukan Kolonial Belanda. Meskipun ekspansi Kolonial Belanda didorong oleh pencarian emas, rempah-rempah ke Papua, tetapi motif yang tak kalah penting menurut 
Muller (2008:102) adalah alasan untuk mencari "jiwa" meski dilakukan agak terselubung, yaitu untuk memperkenalkan agama Kristen pada daerah taklukan. Di bawah Kolonialisme Belanda daerahdaerah dataran tinggi dan daerah terpencil adalah sasaran bagi missionaris Kristen. Namun demikian, baik orang Belanda maupun Inggris tidak melakukan penginjilan Kristen di antara penduduk Muslim yang sudah mapan karena mereka sadar bahwa hal itu bisa merongrong keamanan dan ketertiban yang sangat penting bagi kepentingan Eropa (Hefner 2008: 35).

\section{Relasi Dalam Berkomunitas}

Saat ini pun kita bisa dengan mudah menyaksikan bagimanan kehidupan beragam itu berjalan pada level komunitas (dalam hidup sehari-hari). Pada level komunitas orang Papua sudah terbiasa saling menghormanti antar suku dan agama, kawin-mawin dengan berbeda agama dan suku. Bahkan proses proses asimiliasi yang sesungguhnya kemudian ditunjukkan dalam budi bahasa seperti muculnya istilah "Jamer" (Jawa-Merauke), "Mujair" (Muka Jawa Irian), "Perancis" (Peranakan Cina Serui), "Irma" (Irian-Makassar)6.

\footnotetext{
${ }^{6}$ Di luar itu, berbagai ungkapan yang dugunakan setiap kabupaten untuk mengeksperisikan toleransi dan keberagaman mereka, seperti slogan yang diusung oleh kota Jayapura, Hen Techahi Yo Onomi T'mar Hanased, yang bermaknamembangun kota Jayapura untuk kemuliaan Tuhan. Awetako Enaa Agapida, Slogan yang digunakan kabupaten Paniai
}

Dalam kehidupan berkomunitas, secara emosional mereka terikat dalam suatu identitas kolektif untuk berinteraksi dalam berbagai aktivitas sosial. Hal ini terlihat jelas dalam berbagai kehidupan seharihari, dimana orang tanpa meminta bantuan, kerabat yang lain datang dengan sendirinya mengambil bagian di dalamnya. Misalnya dalam upacara kematian, kelahiran, membuka kebun baru atau membangun rumah. Dalam setiap kegiatan tersebut, dengan sendirinya orang akan datang untuk menyumbangkan tenaga atau berupa materinya. Hubungan ini biasanya dilakukan secara individu maupun kelompok. Misalnya dalam membuka kebun ada yang membuka sendiri, dan ada yang dikerjakan dengan mengundang sejumlah keluarga besar untuk membuka kebun secara bersama-sama, dengan pola gotong- royong berdasarkan ikatan perkawinan dari nenek moyang tertentu.

\section{Kesimpulan}

Berbagai fakta sosial yang telah terjadi di Papua menunjukkan adanya dinamika

untuk menjelaskan bahwa arti hari esok lebih baik dari hari kemarin. Izakod Bekai Izakod Kai, Semboyan yang digunakan oleh Kabupaten Merauke, yangmemiliki arti "satu hati satu tujuan". Dari Kabupten Waropen mengusung tema Ndi Sowosio Ndi Korako yaitu mempersatukan seluruh masyarakat yang mendiami Kabupten Waropen baik dari masyarakat pantai, pegunungan dan kaum pendatang. Dari Kabupten Mamberamo menggunakan semboyan Nabuwa Kabuwa Yabu Eruwok, yang berarti "membangun dalam kasih". 
komunitas-komunitas lokal di Papua dalam merajut perbedaan diantara mereka. Kelompok-kelopok etnik dan budaya yang berbeda denominasinya telah mampu membangun relasi sosial melalui mekanisme budaya. Modal budaya untuk merajut perbedaan berupa budaya komunal seperti makan bersama, agama bersaudara, satu tungku tiga batu, perkawinan di luar klan atau marga dapat menjadi perekat sosial diantara mereka. Meskipun sering terjadi konflik antar suku, namun komunitas-komunitas adat tersebut memiliki cara untuk menyatukan kembali kelompok-kelompok yang berkonflik, yaitu dengan melalui mekanisme budaya, sperti "makan bersama", "bakar batu" dan disertai dengan pemotongan hewan kurban.]

\section{Daftar Pustaka}

Abdullah, Irwan. 2005. Solusi Antropologi untuk Indonesia dalam Teori, Etnografi dan Refleksi. Yogjakarta: PintalKanisius.

Alqadrie, Syarif Ibrahim. 1999. "Konflik Etnis di Ambon dan Sambas: Suatu Tinjauan Sosiologis." Antropologi Indonesia Th. XXIII. (58). Jakarta: Yayasan Obor Indonesia.

Bachtiar, H. W. 1993. "Sejarah Irian Jaya" dalam Irian Jaya Membangun Masyarakat Majemuk. Koentjaraningrat ed. Jakarta: Jambatan.

Geertz, Clifford. 1986. Mojokuto: Dinamika Sosil Sebuah Kota di Jawa. Jakarta: Temprint.
——_. 1989. Penjajah dan Raja: Perubahan Sosial dan Modernisasi Ekonomi di Dua Kota di Indonesia. Jakarta: Yayasan Obor Indonesia.

Haviland, William A. 1985. Antropologi. edisi keempat. Jakarta: Erlangga.

Hefner, Robert W. 2007. "Pendahuluan: Multikulturalisme dan Kewarganegaraan di Malaysia, Singapura dan Indonesia", dalam Politik Multikultural. Yogyakarta:Impulse-Kanisius.

Heider, Karl G. 1970. The Dugun Dani. New York: Wenner Gren Foundation for Anthropologhical Recearch Inc.

Iribaram, Suparto. 2011."Satu Adat Tiga Agama: Meneropong Aktifitas Masyarakat di Teluk Fatipi Fakfak Papua" dalam Kumpulan Makalah yang Dipresentasikan dalam the 11 Anual Conference on Islamic Studies (ACIS), Bangka Belitung 10-12 Oktober 2011.

Koentjaraningrat. 1970. Keseragaman dan Aneka Warna Masyarakat Irian Barat. Jakarta: Lembaga Ilmu Pengetahuan ilmiah.

Koentjaraningrat. 1993. Irian Jaya Membangun Masyarakat Majemuk. Jakarta: Jambatan.

Laksono, P. M. 2009. "Rujukan LembagaLembaga Demokrasi Dalam Ranah Komunitas Lokal". dalam Perspektif Budaya: Kumpulan Tulisan Koentjaraningrat Memorial Lectures IV/2004-2008, Jakarta: Raja Grafindo Persada.

Mahsun. 2015. Indonesia dalam Perspektif Politik Kebahasaan. Jakarta: Raja Grafindo. 
Mansoben, J. R. 1995. Sistem Politik Tradisional di Irian Jaya. Jakarta: LIPIRUL.

Maunati, Yekti. 2006. Identitas Dayak: Komodifikasi dan Politik Kebudayaan, Yogyakarta, LKiS.

Misrawi, Zuhairi. 2009. Madinah, Kota Suci, Piagam Madinah, dan Teladan Rasulullah SAW. Jakarta: Kompas, 2009.

Mulder, Neils. 1999. $\quad$ Agama, Hidup Seharihari dan Perubahan Budaya: Jawa, Muangthai, dan Filipina. Jakarta, Gramedia.

Muller, Kal. 2006. Mengenal Papua, Indonesia. Daisy Word Books.

Nawiruddin dan Malla. 2013. Pembinaan Ummat Berbasis Multikultural. Jakarta: Sejahtera Kita

Pariela, Toni D. 2009. "Politik Identitas dan Politik Perilaku (Kasus Maluku) dalam Renai Politik Identitas dalam Dinamika Politik di Berbagai Daerah di Indonesia". Percik IX (2): 57-103.

Pospisil, L. 1963. Kapauku Papuan Economy. New Heaven: Yale University.

Purwanto, Bambang. 2012. "Merajut Kebinekaan dan Kearifan Budaya Bagi Kemajuan dan Kesejahteraan Indonesia", Pidato IImiah disampaikan pada Rapat Universitas Gadjah Mada dalam Rangka Peringatan Dies Natalis ke-63. Yogyakarta, 19 Desember 2012.

Rahman, Abd. et.al. 2008. Sejarah Teluk Bintuni: Awal Pemerintahan Kolonial Belanda di Papua Hingga Terbentuknya Pemerintahan Definitif Kabupaten Teluk Bintuni Pasca Pemekaran (19982006).Yogyakarta: Lanarka Publishing.

Sahlins, Marshal D. 1963. "Poor Man, Rich Man, Big-Man, Chief: Political Types in Melanesia and Polynesia, Comparative Studies." Society and History 5 (3): 285-303

Samaduda, Max dan Baiquni, M. 2000. "Pranata/Lembaga Adat dan Organisasi Sosial" dalam Menjaga Alam Membela Masyarakat: Komunitas Lokal dan Pemanfaatan Mangrove di Teluk Bintuni. Yogyakarta: PSAP-UGM.

Sanggenafa, N. dan Koentjaraningrat. 1993. "Pertukaran Kain Timur di Daerah Kepala Burung dalam Irian Jaya Membangun Masyarakat Majemuk. Koentjaraningrat ed. Jakarta: Djambatan.

Timmer, Jaap. 2007. Desentralisasi Salah Kaprah dan Politik Elit di Papua dalam Politik Lokal di Indonesia. Jakarta: KITLV.

Wilson, Peter J.1988. The Domestication of the Human Species. New Haven and London: Yale University Press. 


\section{Author Guidelines}

\section{A. Persyaratan Umum}

1. Naskah merupakan hasil penelitian sosial keagamaan dan modernitas yang sudah diformat sesuai pola penulisan artikel jurnal ilmiah.

2. Naskah diutamakan ditulis dalam Bahasa Inggris.

3. Naskah merupakan karya orisinil (bukan plagiasi) dan belum pernah dimuat di jurnal atau media cetak/online lainnya.

4. Naskah dikirim ke Redaksi JSW: Jurnal Sosiologi Walisongo melalui submission Open Journal Systems (OJS) pada http://journal.walisongo.ac.id/index.php/jsw

5. Naskah diketik menggunakan Microsoft Word format RTF, font Times New Roman, size 12 pt, 1,5 spasi, ukuran halaman A4, dengan panjang tulisan 20-25 halaman (sekitar 5.000 - 7.000 kata).

6. Untuk menperoleh keterangan lebih lanjut, silakan menghubungi redaksi melalui email: jurnal.sosiologi@walisongo.ac.idatau menghubungi kantor redaksi (024) 76435986.

\section{B. Persyaratan Khusus}

1. Naskah merupakan hasil penelitian dalam bidang sosial keagamaan dan modernitas.

2. Naskah tidak mencantumkan nama penulis, instansi, dan alamat email. Nama penulis, instansi, dan alamat email dicantumkan saat melakukan registrasi OJS dan pengisian metadata naskah.

3. Naskah memuat:

a. Judul, dengan ketentuan:

- Judul merupakan rumusan pokok bahasan yang singkat, padat, dan jelas.

- Dalam judul sudah tercantum variabel-variabel utama penelitian.

- Judul diketik dengan hurup kapital tebal (capital, bold).

b. Abstrak, dengan ketentuan:

- Abstrak ditulis dalam bahasa Inggris dan bahasa Indonesia. 
- Abstrak merupakan intisari dari pokok bahasan naskah.

- Abstrak ditulis dalam satu paragraf berjarak satu spasi, dengan panjang 100250 kata.

- Abstrak disajikan secara singkat dan jelas, dengan memuat empa. argumentasi logis, perlunya dilakukan penelitian untuk memecahkan masalah, pendekatan yang digunakan (metode), hasil yang dicapai, serta simpulan yang diperoleh (IMRAD: introduction, methods, results, analysis and discussions).

c. Kata Kunci (keywords) maksimal 5 (lima) kata.

d. Isi naskah, dengan sistematika sebagai berikut:

- Pendahuluan yang meliputi latar belakang masalah, perumusan masalah, tujuan dan manfaat penelitian, serta metodologi yang digunakan (IMRAD: introduction, methods, results, analysis and discussions).

- Review pustaka yang berisi kajian teoretik dan hasil penelitian terdahulu yang relevan.

- Hasil dan pembahasan.

- Simpulan dan rekomendasi.

- Daftar pustaka.

4. Rujukan menggunakan ASA (American Sociological Association).[] 


\section{ACKNOWLEDGEMENTS}

The members of the editorial team of JSW: Jurnal Sosiologi Walisongo extend the gratitude to all the reviewers who have contributed to the peer review process of the manuscripts in Vol 1, No 2 (2017). Professional support and assistance from all respected reviewers have made this journal qualified to be published:

1. Abu Rokhmad, Universitas Islam Negeri Walisongo, Semarang

2. Agus Nurhadi, Universitas Islam Negeri Walisongo, Semarang

3. Misbah Zulfa Elizabeth, Universitas Islam Negeri Walisongo, Semarang

4. Muhyar Fananai, Universitas Islam Negeri Walisongo, Semarang

5. Najahan Musyafak, Universitas Islam Negeri Walisongo, Semarang

6. Thohir Yuli Kusmanto, Universitas Islam Negeri Walisongo, Semarang

7. TriMarhaeni Pudji Astuti, Universitas Negeri Semarang 


\section{\begin{tabular}{l|l} 
JW & $\begin{array}{l}\text { JURNAL } \\
\text { SOSIOLOGI } \\
\text { WALISONGO }\end{array}$
\end{tabular}}

JSW: Jurnal Sosiologi Walisongo - ISSN 2503-3166 (print) ISSN 2503-3182 (online) is a critical, reflective, and transformative academic media that is published by Laboratorium Sosiologi, Fakultas IImu Sosial dan IImu Politik, Universitas Islam Negeri Walisongo Semarang, in the effort for developing the discipline of Sociology having the perspective of unity of sciences. Article is based on research in all division of sociology like sociology of religion, sociology of politic, sociology of law, sociology of development, urban/rural sociology, democracy, social ethic, anthropology, community development, social philosophy, gender, and social welfare. 